\title{
Synthesis, Crystal Structure and in vitro DNA Binding Studies of Combretastatin A-4 Analogue
}

\author{
Masood Ahmad Rizvi, ${ }^{1, *}$ Yuvraj Dangat, ${ }^{2}$ Zahid Yaseen, ${ }^{3}$ Vivek Gupta, ${ }^{4}$ Khaliquz Zaman Khan ${ }^{1}$
}

\footnotetext{
1 Department of Chemistry, University of Kashmir, Hazratbal Srinagar,190006, J\&K, India

2 Physical Chemistry Division, CSIR-National Chemical Laboratory, Pune - 411008, India

${ }^{3}$ Department of Civil Engineering, Islamic University of Science and Technology, Kashmir 192122, India

4 Department of Physics, University of Jammu, Babasaheb Ambedkar Road, New Campus, Jammu Tawi - 180 006, J\&K, India

* Corresponding author's e-mail address: masoodku2@gmail.com
}

RECEIVED: May 30, 2015 * REVISED: November 5, 2015 * ACCEPTED: November 15, 2015

\begin{abstract}
Synthesis of a novel Combretastatin A-4 analogue using Schiff's reaction of benzil and 4-aminoantipyrine has been achieved under solvent free conditions. The structure of compound was examined spectroscopically and confirmed from single crystal diffraction studies. The synthesized Combretastatin A-4 analogue was investigated for its DNA binding ability as the plausible mechanism for its antitumor activity. The binding propensity of the synthesized compound with calf-thymus (CT) DNA was monitored with absorption and emission spectrophotometric titrations. The calculations predict a binding constant of $7.24 \times 10^{4}$ for the complex of the synthesized compound with CT DNA which is comparable in magnitude to that of DNA binding of bactericidal drug enoxacin and typical intercalation indicator ethidium bromide (EB). Competitive binding studies of the synthesized compound with EB using fluorescence titration reveal that it displaces the DNA-bound EB and binds in intercalative mode which was further supported by circular dichroism (CD) spectroscopy. The probable site and binding energy of the compound with DNA was further theoretically investigated by molecular docking studies. The significant DNA binding ability of the synthesized Combretastatin A4 analogue as revealed from this study could be related to the anticancer activity of the Combretastatin A4.
\end{abstract}

Keywords: crystal structure, DNA binding, combretastatin A-4, benzil, bio-physical, phenazones, fluorescence, ethidium bromide.

\section{INTRODUCTION}

$\mathbf{S}^{n}$ YNTHESIS of specially designed compounds for specific applications through an environmentally benign methodology is one of the contemporary challenges. ${ }^{[1]} 4$-Aminoantipyrine belongs to the class of phenazones, a predominantly useful heterocyclic compounds, known for their significant role in organic synthesis ${ }^{[2]}$ and diverse biological activity. ${ }^{[3]}$ Benzil (an aromatic 1,2 diketone) is a common building block in organic synthesis which is also reported to be a strong inhibitor of mammalian carboxylesterase enzymes. ${ }^{[4]}$ Recently metabolic enzyme expression has been linked to metabolic alterations which are being regarded as a hallmark of cancer. ${ }^{[5]}$ In continuation of our work on anti cancer compounds ${ }^{[6-10]}$ a schiff base of benzil and 4-aminoantipyrine - the two privileged molecules of drug development was designed. The motivation for selecting benzil amongst a plethora of aromatic 1,2 diketones is its prominent resemblance to anticancer natural product Combretastatin (Figure 1) which has served as a fundamental scaffold for the synthesis of large number of compounds with antitumor activity. ${ }^{[11,12]}$ The presence of<smiles>COc1ccc(/C=C\c2cc(OC)c(OC)c(OC)c2)cc1O</smiles><smiles>Cc1c(/N=C(/C(=O)c2ccccc2)c2ccccc2)c(=O)n(-c2ccccc2)n1C</smiles>

Figure 1. Structural resemblance of Compound 1 with anticancer drug Combretastatin A-4. 
two aryl rings with hydrogen bonding groups and the restricted rotation about the olefinic bridge in Combretastatin is considered crucial for their anticancer activity. ${ }^{[13]}$ The benzil moiety in the synthesized schiff base (compound 1) has two aryl rings, hydrogen bonding carbonyl group and restricted rotation due to the bulky antipyrine group, hence the synthesized compound 1 has a close resemblance to the pharmacophore of the Combretastatin. Since DNA is considered to be a primary target of most of the anticancer compounds and essentially based on the idea that compounds with planar aromatic rings are known to be its intercalators ${ }^{[14]}$ an investigation of DNA binding propensity of synthesized compound was evaluated using different biophysical methods. ${ }^{[15]}$ Even though DNA binding ability of a vast number of compounds has been reported, ${ }^{[16,17]}$ the point of interest in this study is metal free DNA binding ability of a natural product analogue synthesized from two bioactive constituents.

\section{EXPERIMENTAL}

\section{Materials}

All reagents and solvents used (4-aminoantipyrine, benzil, dichloromethane, methanol) were of analytical grade obtained from Sigma-Aldrich Chemicals Pvt. Ltd. and were used without further purification. The calf Thymus DNA was purchased from Bangalore Genei, (India). Silica gel coated aluminum plates were used for TLC monitoring of reactions. The synthesized Schiff base compound was soluble at room temperature in Tris- $\mathrm{HCl}$ buffer $(\mathrm{pH}=7.2)$ in presence of $1 \%$ DMSO solution. All the experimental solutions and dilutions of compound 1 were done using the Tris- $\mathrm{HCl}$ buffer $(\mathrm{pH}=$ 7.2) in presence of $1 \%$ DMSO solution. The stock solution of CT-DNA was prepared in Tris- $\mathrm{HCl}$ buffer $(\mathrm{pH}=7.2)$ stored at $4{ }^{\circ} \mathrm{C}$ and consumed within 2 days.

\section{Instrument and physical measurements}

The IR spectrum was recorded as $\mathrm{KBr}$ pellet on Shimadzu IR408 Perkin-Elmer 1800 (FTIR) spectrophotometer and the values are given in $\mathrm{cm}^{-1}$. Elemental analysis $(\mathrm{C}, \mathrm{H}, \mathrm{N})$ was performed using Carlo Erba analyzer model 1108. An HR ESI-MS spectrum was recorded on G6540-UHD LC/MS QTOF (Agilent Technologies). ${ }^{1} \mathrm{H}$ NMR spectra were recorded on Bruker-Avance DPX FT-NMR $400 \mathrm{MHz}$ spectrometer with TMS as an internal standard. The single crystal $X$ ray structure was obtained using $X^{\prime}$ calibur CCD area-detector diffractometer. The UV-Vis measurements were recorded on a 177 Beckman DU 40 Spectrophotometer (USA) using a cuvette of $1 \mathrm{~cm}$ path length. Fluorescence measurements were recorded on a Shimadzu 184 Spectrofluorimeter -5000 (Japan) spectra in the range of $200-330 \mathrm{~nm}$ around $25^{\circ} \mathrm{C}$. The
CD spectra were collected using a Jasco J-815 Circular dichroism (CD) Spectropolarimeter. The geometries were optimized with the Gaussian 03 quantum chemistry package using Becke's three parameter hybrid functional (B3LYP) and the 6-311G (d,p) ++ basis set. The rigid molecular docking studies were performed using HEX 6.1 software. The Hex 6.1 performs protein docking using Spherical Polar Fourier Correlations, which needs the ligand and the receptor input in PDB format.

\section{General Procedure}

Synthesis of 1,5-Dimethyl-4-(2-oxo-1,2-diphenyl-ethylideneamino)-2-phenyl-1,2-dihydro-pyrazol-3-one Compound 1:

The compound 1 was synthesized by fusion of 1:1 molar ratio of 4-aminoantipyrine and benzil. The solid 4aminoantipyrine was first melted over silicone oil bath maintained around $110{ }^{\circ} \mathrm{C}$ followed by slow addition of solid benzil (m.p. $97^{\circ} \mathrm{C}$ ) to the molten state of 4-aminoantipyrine. The reaction mixture was stirred over a magnetic stirrer for $1 \mathrm{~h}$ and the progress of reaction was monitored using TLC. After completion of reaction yellow colored solid product got separated, which was filtered, air dried and recrystallized from methanol and dichloromethane $(4: 1)$ solvent mixture as pale yellow crystals. Yield: $74 \%$; m.p. $145-$ $47^{\circ} \mathrm{C}$. IR (KBr) cm ${ }^{-1} 1650,1550$ and $1590 \mathrm{~cm}^{-1}$. ${ }^{1} \mathrm{H} \mathrm{NMR}\left(\mathrm{CDCl}_{3}\right.$, $400 \mathrm{MHz}): \delta / \mathrm{ppm} 7.55-7.41(\mathrm{~m}, 4 \mathrm{H}), 7.41-7.29(\mathrm{~m}, 8 \mathrm{H}), 7.27-$ $7.17(\mathrm{~m}, 3 \mathrm{H}), 3.03(\mathrm{~s}, 3 \mathrm{H}), 2.36(\mathrm{~s}, 3 \mathrm{H})$. HR ESI-MS $(\mathrm{m} / \mathrm{z})$ calcd. for $\mathrm{C}_{25} \mathrm{H}_{21} \mathrm{~N}_{3} \mathrm{O}_{2}[\mathrm{M}+\mathrm{H}]^{+}$396.1707, found 396.1721. Anal. Calcd. mass fractions of elements, $w / \%$ for $\mathrm{C}_{25} \mathrm{H}_{21} \mathrm{~N}_{3} \mathrm{O}_{2}$ : C 75.93, H 5.35, N 10.63; found: C 76.58, H 4.93, N 9.87.

\section{Crystal Structure Determination and Refinement}

The X-ray intensity data of 8516 reflections (of which 4083 unique) were collected on $X^{\prime}$ calibur CCD area-detector diffractometer equipped with graphite monochromated MoK $\alpha$ radiation $(\lambda=0.71073 \AA$ ). The dimension of crystal used for data collection was $0.30 \times 0.20 \times 0.20 \mathrm{~mm}$. The cell dimensions were determined by least-squares fit of angular settings of 2842 reflections in the $\theta$ range 3.81 to $28.85^{\circ}$. The intensities were measured by $\omega$ scan mode for $\theta$ ranges 3.56 to $26.00^{\circ} .2755$ reflections were treated as observed: $I>2 \zeta(I)$. The structure was solved by direct methods using SHELXL 97. All non-hydrogen atoms of the molecule were located in the best E-map. Full-matrix least-squares refinement was carried out using SHELXL 97. The final refinement cycles converged to $R=0.0441$ and $w R\left(F^{2}\right)=0.1113$ for the observed data. Residual electron densities ranged from 0.215 to $0.203 \AA^{-3}$. Atomic scattering factors were taken from International Tables for X-ray Crystallography (1992, Vol. C, Tables 4.2.6.8 and 6.1.1.4). The crystallographic data are summarized in Table 1 
Table 1. Crystal data and structure refinement parameters of Compound 1

\begin{tabular}{|c|c|c|}
\hline CCDC No & \multicolumn{2}{|l|}{957471} \\
\hline Crystal description & \multicolumn{2}{|l|}{ Block, Yellow } \\
\hline Empirical formula & \multicolumn{2}{|l|}{$\mathrm{C}_{25} \mathrm{H}_{21} \mathrm{~N}_{3} \mathrm{O}_{2}$} \\
\hline Formula weight & \multicolumn{2}{|l|}{395.45} \\
\hline Radiation wavelength & \multicolumn{2}{|c|}{$\operatorname{Mo}-K \alpha(\lambda=0.71073 \AA)$} \\
\hline Temperature. & \multicolumn{2}{|c|}{$293(2) \mathrm{K}$} \\
\hline \multirow[t]{3}{*}{ Unit cell dimensions } & $a=9.8747(4) \AA$ & $\alpha=90^{\circ}$ \\
\hline & $b=14.0319(8) \AA$ & $B=90.568(4)^{\circ}$ \\
\hline & $c=15.0386(7) \AA$ & $\gamma=90^{\circ}$ \\
\hline Crystal system; Space group & \multicolumn{2}{|c|}{ Monoclinic; P121/n1 } \\
\hline Unit cell volume & \multicolumn{2}{|c|}{$2083.66(18) \AA^{3}$} \\
\hline Z & \multicolumn{2}{|l|}{4} \\
\hline Absorption coefficient & \multicolumn{2}{|l|}{$0.081 \mathrm{~mm}^{-1}$} \\
\hline$F(000)$ & \multicolumn{2}{|l|}{832} \\
\hline$\theta$ range for entire data collection & \multicolumn{2}{|l|}{$-3.56^{\circ}<\theta<26.0^{\circ}$} \\
\hline Range of indices & \multicolumn{2}{|c|}{-17 to $9, I=-18$ to 17} \\
\hline Reflections collected / unique & \multicolumn{2}{|l|}{$8516 / 4083$} \\
\hline Reflections observed $(I>2 \sigma(I))$ & \multicolumn{2}{|l|}{2755} \\
\hline Refinement & \multicolumn{2}{|c|}{ Full-matrix least-squares on $\mathrm{F}^{2}$} \\
\hline Final R & \multicolumn{2}{|l|}{0.0441} \\
\hline$w R\left(F^{2}\right)$ & \multicolumn{2}{|l|}{0.1113} \\
\hline Goodness-of-fit & \multicolumn{2}{|l|}{1.025} \\
\hline
\end{tabular}

\section{Preparation of DNA Stock Solution}

The stock solution of DNA was prepared by dissolving CT DNA in Tris- $\mathrm{HCl}$ buffer ( $30 \mathrm{mM}, \mathrm{pH}=7.2$ ). The purity of DNA was verified by monitoring the ratio of absorbance at 260 $\mathrm{nm}$ to that at $280 \mathrm{~nm}$, which was in the range of 1.8-1.9. The concentration of the DNA was determined spectrophotometrically using $\varepsilon=6600 \mathrm{~mol} \mathrm{~L}^{-1} \mathrm{~cm}^{-1}$. [18]

\section{Absorption Spectrometry}

The absorbance value of the compound 1 was recorded in the absence and presence of DNA in the range of 225-550 nm. The reference solution was the corresponding Tris- $\mathrm{HCl}$ buffer solution. While measuring the absorption spectra, equal amount of DNA was added to both the compound and reference solutions to eliminate the absorbance of DNA itself.

\section{Emission Spectroscopy}

The binding constants $K b$ of the compound (1) with DNA was obtained by the fluorescence titration method. The fluorescence quenching with increasing concentration of DNA was recorded after exciting the compound solution at $290 \mathrm{~nm}$, using 10/10 nm slit widths.

\section{Circular Dichroism (CD) Studies}

The CD spectra were recorded in the region of 330-200 nm with a scan speed of the $200 \mathrm{~nm} / \mathrm{min}$ in a cuvette of $2 \mathrm{~mm}$ path length. Three scans were recorded and averaged.

\section{Viscosity Studies}

The viscosity measurements were carried out using Oswald capillary viscometer. The flow time was measured with a digital stopwatch, and each sample was tested three times to get an average calculated time. The data were presented as $\left(\eta / \eta_{0}\right)^{1 / 3}$ versus concentrations of DNA/compound 1 a ratio where $\eta$ is the viscosity of the solution in the presence of a compound $1 ; \eta_{0}$ is the viscosity of the DNA solution only.

\section{Molecular Docking Experiments}

The rigid molecular docking studies were performed using HEX 6.1 software. The crystal structure of the B-DNA dodecamer d(CGCGAATTCGCG)2 (PDB ID: 1BNA) was downloaded from the protein data bank. The energy optimized structure of compound $\mathbf{1}$ was used for the docking study. Visualization of the docked pose has been done by using PyMol (http://pymol.sourceforge.net/) molecular graphic program.

\section{RESULTS AND DISCUSSION}

The conventional synthesis employs refluxing reactant mixtures in high boiling organic solvents, followed by extensive chromatographic workup of purification and re-crystallization. At present environmentally benign synthetic methods are receiving considerable attention and solvent-free protocols are in demand. While embracing the principles of 


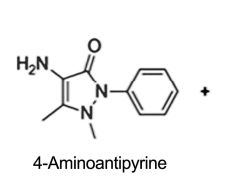<smiles>O=C(c1ccccc1)c1ccccc1</smiles>

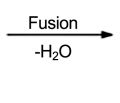

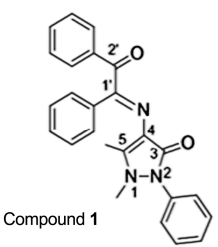

Scheme 1. Synthesis of Compound 1.

green chemistry, ${ }^{[19]}$ we attempted a solvent free target synthesis, of a hitherto unknown compound 1 . It was synthesized by condensing of equimolar quantities of 4amino antipyrine and benzil as shown in Scheme 1. The synthesis involves a one pot, single step, solvent free reaction using non-conventional fusion method in which the reactant with higher melting point (4-aminoantipyrine, m.p. $110^{\circ} \mathrm{C}$ ) was first liquefied (melted) and the other with lower melting point (benzil, $97^{\circ} \mathrm{C}$ ) was added to the molten state of former. Thus, equimolar amounts of 4-aminoantipyrine and benzil were condensed under solvent less conditions at $110^{\circ} \mathrm{C}$ in a silicone oil bath and the reaction mixture was magnetically stirred for $1 \mathrm{~h}$. The compound 1 was crystallized by $s$ low solvent evaporation method using methanol and dichloromethane $(4: 1)$ mixture.

The structure of the synthesized compound 1 was elucidated by IR, ${ }^{1} \mathrm{H}$ NMR, Mass spectrometry and Elemental (CHN) analysis, which was also unambiguously confirmed through single crystal X-ray crystallographic study. An ORTEP view of the compound with atomic labeling is shown in (Figure 2). The geometry of the molecule was calculated using the WinGX, PARST and PLATON softwares. The extended structure of the compound 1 shows weak intermolecular interactions like $\pi-\pi$ stacking, $\mathrm{C}-\mathrm{H}-\pi, \mathrm{C}-\mathrm{H}-\mathrm{O}$ and $\mathrm{C}-\mathrm{H}-\mathrm{N}$ type intermolecular interactions (Figure 3 ). The crystallographic data is summarized in Table 1 . The measured $\pi-\pi$ distances of 3.704 and $3.253 \AA$ respectively suggests $\pi-\pi$ stacking and $\mathrm{C}-\mathrm{H}-\pi$ interaction. ${ }^{[20,21]}$ The distances of 2.614 and $2.734 \AA$ respectively indicate a good hydrogen bonding of phenyl hydrogen with carbonyl oxygen and nitrogen atoms in compound 1.

\section{DNA binding studies}

\section{ABSORPTION SPECTRAL STUDIES}

The Uv-visible absorption spectra of compound 1 exhibits intense absorption bands at $290 \mathrm{~nm}$ and a shoulder at 400 $\mathrm{nm}$ attributed to $\pi-\pi^{*}$ and $n \rightarrow \pi^{*}$ intraligand transition, respectively. The hypochromism or decrease in absorption intensity of the compound 1 observed on gradual addition of CT DN A $\left(0.00-6.50 \times 10^{-5} \mathrm{~mol} \mathrm{~L}^{-1}\right)$ to its fixed concentration $\left(1.11 \times 10^{-4} \mathrm{~mol} \mathrm{~L}^{-1}\right.$ ) (Figure 4), was attributed to interaction of its $\pi^{*}$ molecular orbitals with the $\pi$-orbitals of the DNA base pairs, resulting in a decreased $\pi-\pi^{*}$ transition

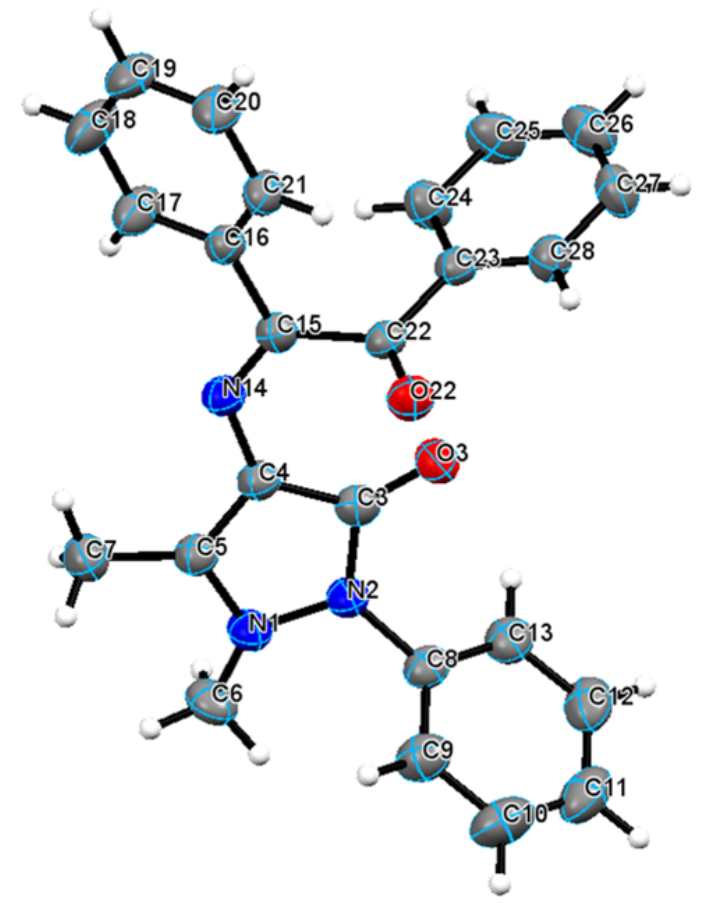

Figure 2. ORTEP view of the Compound 1 with displacement ellipsoids drawn at 50\%. $\mathrm{H}$ atoms are shown as unlabelled white spheres of arbitrary radii.

probability and hence hypochromism. ${ }^{[22]}$ The binding constant $K b$ quantifying binding propensity of compound $\mathbf{1}$ with CT DNA, was obtained from the change in the absorbance spectra with increasing concentrations of CT DNA. The binding constant of $7.24 \times 10^{4} \mathrm{~mol} \mathrm{~L}^{-1}$ was calculated from the ratio of slope to the intercept in the inset plot of (Figure 4) using Wolfee-Shimmer equation. ${ }^{[23]}$

$$
\frac{[\mathrm{DNA}]}{\left(\varepsilon_{a}-\varepsilon_{f}\right)}=\frac{[\mathrm{DNA}]}{\left(\varepsilon_{b}-\varepsilon_{f}\right)}+\frac{1}{K_{b}\left(\varepsilon_{b}-\varepsilon_{f}\right)}
$$

where [DNA] is the concentration of DNA in base pairs, and $\varepsilon_{a}$ is the apparent extinction coefficient ( $A_{\text {abs }} /$ [compound $1], \varepsilon_{f}$ is the extinction coefficient of the compound $\mathbf{1}$ when free in solution and $\varepsilon_{b}$ is its extinction coefficient when fully

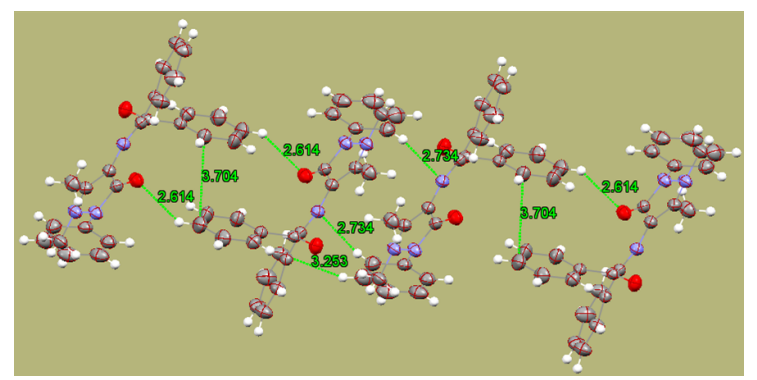

Figure 3. Intermolecular forces of attraction in Compound 1. 


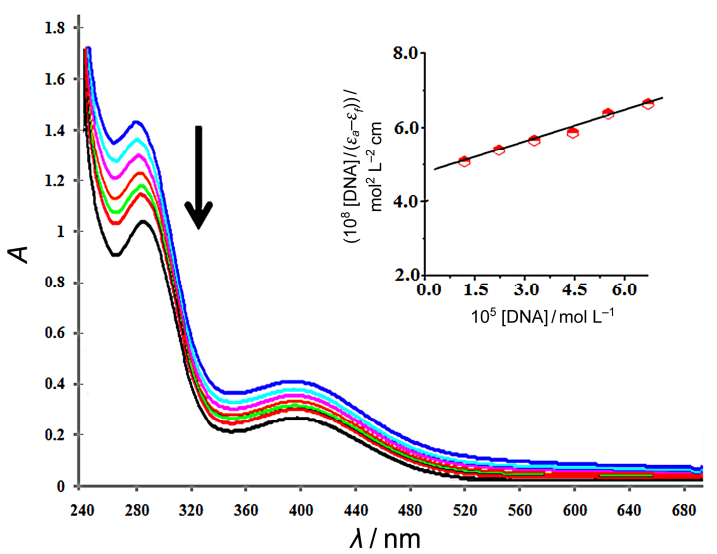

Figure 4. Absorption spectral changes for a fixed concentration of compound 1 upon addition of increasing amounts of CT DNA in $30 \mathrm{mM}$ Tris $\mathrm{HCl}$ buffer $\mathrm{pH}=7.2$. Inset: Plots of [DNA] $/\left(\varepsilon_{q}-\varepsilon_{f}\right)\left(\right.$ in $\left.\mathrm{mol}^{2} \mathrm{~L}^{-2} \mathrm{~cm}\right)$ vs. [DNA] for the titration with compound 1., $\bullet$ experimental data points, full lines, linear fitting of the data. [DNA] $=0.00-6.50 \times 10^{-5} \mathrm{~mol} \mathrm{~L}^{-1}$, [Compound 1] $=1.11 \times 10^{-4} \mathrm{~mol} \mathrm{~L}^{-1}$.

bound to DNA. A plot of [DNA] / $\left(\varepsilon_{a}-\varepsilon_{f}\right)$ versus [DNA] gave a slope $1 /\left(\varepsilon_{b}-\varepsilon_{f}\right)$ and $Y$ axis intercept equal to $1 / K_{b}\left(\varepsilon_{b}-\varepsilon_{f}\right)$ respectively. Thus intrinsic binding constant $K_{b}$ was calculated from the ratio of the slope to the $Y$ axis intercept.

The calculated magnitudes of $K_{b}$ indicate a considerable binding affinity of compound $\mathbf{1}$ for CT DNA. The observed absorption spectral changes are predictive of intercalative mode of interaction of compound 1 with $\mathrm{CT}$ DNA involving insertion of its aromatic rings between the base pairs of DNA. In order to arrive at the exact mode of

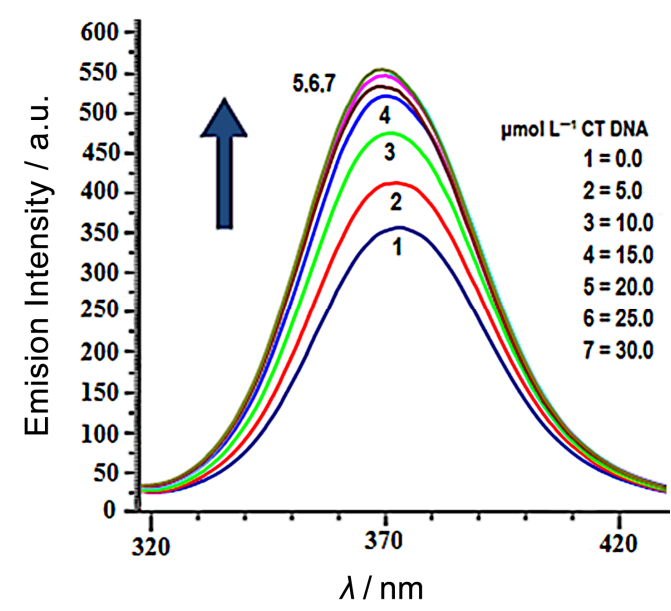

Figure 5. Emission spectral changes for a fixed concentration of the compound 1 upon addition of increasing amounts of CT DNA.in $30 \mathrm{mM}$ Tris- $\mathrm{HCl}$ buffer $\mathrm{pH}=7.2$. [DNA] $=0.00-$ $3.0 \times 10^{-5} \mathrm{~mol} \mathrm{~L}^{-1}$, [Compound 1$]=1.0 \times 10^{-5} \mathrm{~mol} \mathrm{~L}^{-1}$. interaction we further investigated the DNA binding experiments using other techniques.

\section{EMISSION SPECTRAL STUDIES}

The compound 1 on excitation at $290 \mathrm{~nm}$ emits at $374 \mathrm{~nm}$ in the absence of CT DNA. The fluorescence intensity increased with no apparent change in shape and the slight change in position of the emission band $(4 \mathrm{~nm})$ on gradual addition of CT DNA $\left(0.00-3.0 \times 10^{-5} \mathrm{~mol} \mathrm{~L}^{-1}\right)$ to a fixed concentration of compound $1\left(1.0 \times 10^{-5} \mathrm{~mol} \mathrm{~L}^{-1}\right)$ (Figure 5). The hyperchromism in fluorescence intensity of the compound 1 establishes its binding interaction with CT-DNA most probably due to the inaccessibility of solvent water molecules to reach the hydrophobic environment inside the DNA helix and the restricted mobility of the compound at the binding site leading to a decrease in vibrational mode of relaxation. ${ }^{[24]}$ The binding constant value of $7.29 \times 10^{4} \mathrm{~mol} \mathrm{~L}^{-1}$ determined from the Scatchard equation ${ }^{[25]}$ depicts the significant interaction between the compound 1 and CT DNA in comparison to the reported binding constant $\left(6.58 \times 10^{4} \mathrm{~mol} \mathrm{~L}^{-1}\right)$ of a well known DNA intercalator ethidium bromide.[26]

\section{COMPETITIVE DNA-BINDING WITH ETHIDIUM BROMIDE (EB)}

Ethidium bromide (EB, 3,8-diamino-5-ethyl-6-phenyl-phenanthridinium bromide) is a typical intercalator. A competitive binding experiment of compound $\mathbf{1}$ with EB was carried out to ascertain its intercalative mode of DNA interaction. EB on chelation with DNA gives an intense fluorescence however when freed from DNA, EB does not show any noticeable emission. In the competitive binding experiments, the emission spectra of EB-DNA adduct at $595 \mathrm{~nm}$

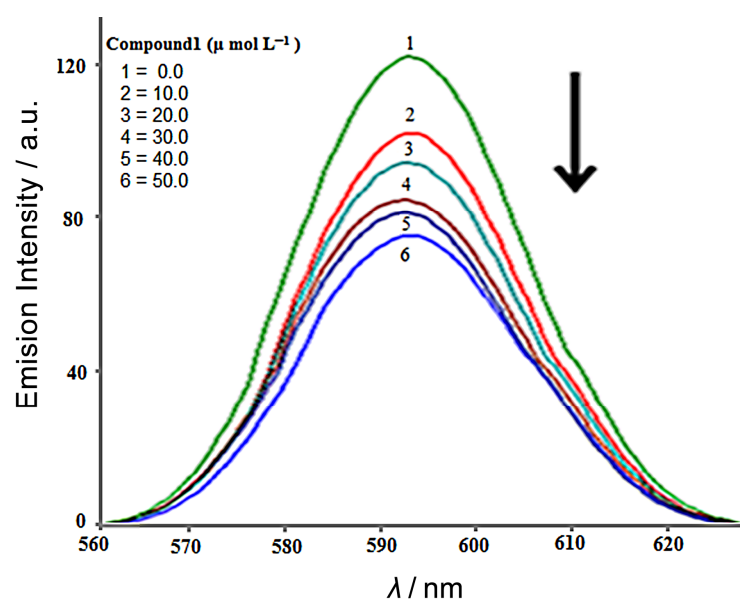

Figure 6. Fluorescence titration of EB-CT DNA complex with compound 1 ; $[\mathrm{DNA}]=[\mathrm{EB}]=1.0 \times 10^{-5} \mathrm{~mol} \mathrm{~L}^{-1}$. Arrow shows change in intensity with increasing concentration of compound $1\left(0.00-5.0 \times 10^{-5} \mathrm{~mol} \mathrm{~L}^{-1}\right)$. 
$\left(\lambda_{e x}=332 \mathrm{~nm}\right)$ in the absence and presence of compound 1 have been recorded. With increasing addition of compound 1 to EB-DNA adduct from the ratio of $1: 1$ to $5: 1$, a decrease in the emission intensity of EB-DNA system was observed indicating competition between EB and compound 1 towards CT-DNA (Figure 6). The significant quenching of EBDNA fluorescence suggests that compound 1 displaces EB from the EB-DNA complex and thus interacts with CT DNA in the intercalative mode at the similar binding site. The fluorescence quenching data were analyzed to obtain the quenching constant using Stern-Volmer equation,

$$
F_{0} / F=1+K_{\mathrm{SV} \cdot}[Q]
$$

Where $F_{0}$ and $F$ denote the steady-state fluorescence intensities in the absence and presence of the quencher (compound 1 ), respectively, $K_{S V}$ is the Stern-Volmer quenching constant and $[Q]$ is the concentration of the quencher. The [Eq. (2)] was applied to determine $K_{\mathrm{sv}}$ by linear regression of a plot of $\left(F_{0} / F\right)-1$ versus concentration of compound 1 . The $K_{\text {sv }}$ value for the compound 1 was found to be $2.88 \times$ $10^{4} \mathrm{~mol} \mathrm{~L}^{-1}$ which is consistent with the electronic absorption results. Comparing the intercalative binding potential of compound 1 with a well known anti-inflammatory drug Naproxen ${ }^{[27]}$ reveals that it brings more quenching of EB-DNA fluorescence even at a lower concentration than naproxen, which confirms the good intercalative binding of compound $\mathbf{1}$.

\section{CIRCULAR DICHROISM (CD) STUDIES}

The covalent binding and intercalation with a drug influence the tertiary structure of DNA and lead to changes in its circular dichroism (CD) spectra. ${ }^{[28]}$ We used CD spectroscopy to identify any change in the structure of the CT DNA upon binding with compound 1 . The $C D$ spectrum of $C T$ DNA in Tris-buffer at $\mathrm{pH}=7.2$ (Figure 7), depicts a positive absorption band at $275 \mathrm{~nm}$ (band I) and, negative absorption (band II) at $245 \mathrm{~nm}$ due to $\pi-\pi$ base stacking and right hand helicity respectively, which is consistent with the characteristic B conformation of DNA. ${ }^{[29]}$ With the sequential addition of compound $1\left(0.4-2.4 \times 10^{-5} \mathrm{~mol} \mathrm{~L}^{-1}\right)$ to a fixed concentration of DNA $\left(2.0 \times 10^{-5} \mathrm{~mol} \mathrm{~L}^{-1}\right)$, the intensity of $275 \mathrm{~nm}$ band got increased while that of $245 \mathrm{~nm}$ band went down (from -2 to -6 ). The changing intensities of two bands result in the formation of isodichroic point at $260 \mathrm{~nm}$ suggesting single complex formation between CT-DNA and compound 1 . The change in the ellipticity at $275 \mathrm{~nm}$ can be explained on the basis of disruption of the stacked bases in order to maximize intercalation of the compound $\mathbf{1}$ with CT DNA. The change at $245 \mathrm{~nm}$ occurs due to change in the hydration layer of DNA, which in turn affects the helicity of DNA. Thus the type of changes in the CD spectra reflect base stacking interactions through intercalation of compound $1 .^{[30]}$ A slight increase in negativity of the band at 211

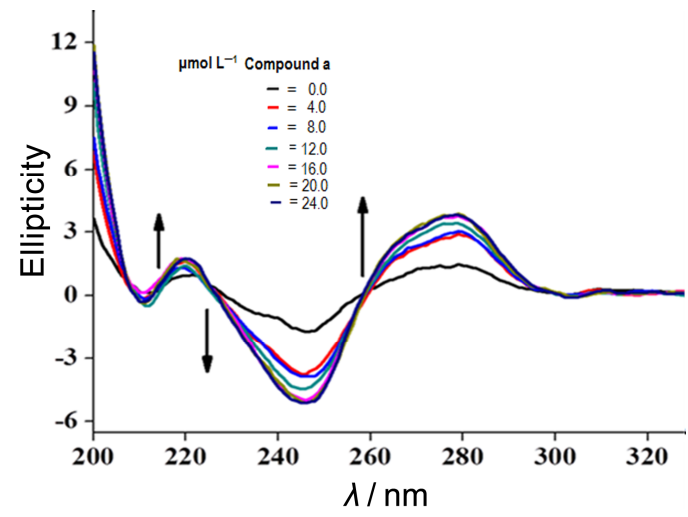

Figure 7. $C D$ spectral changes for a fixed concentration of CT DNA with increasing concentration of synthesized compound 1 in $30 \mathrm{mM}$ Tris- $\mathrm{HCl}$ buffer $\mathrm{pH}=7.2$. [DNA] $=2.0$ $\times 10^{-5} \mathrm{~mol} \mathrm{~L}^{-1}[$ Compound 1$]=\left(0.4-2.4 \times 10^{-5} \mathrm{~mol} \mathrm{~L}^{-1}\right)$.

$\mathrm{nm}$ can be due to a partial B to C-DNA conformational transition of compound 1-DNA adduct as recently reported by Marty et al. ${ }^{[31]}$

\section{VISCOSITY STUDIES}

In classical intercalation the DNA helix lengthens as the base pairs are separated to accommodate the bound ligand leading to increased DNA viscosity. Whereas, a partial, nonclassical ligand intercalation causes a bend in DNA helix reducing its effective length and thereby its viscosity. ${ }^{[32]} A$ plot of relative viscosities $\left(\eta / \eta_{0}\right)^{1 / 3}$ versus [compound 1 ] [ [DNA] was obtained to study any change in viscosity of DNA solution in presence of the increasing molar ratios of compound 1 to DNA. As illustrated in Figure 8, on increasing the molar ratios of the compound 1 to DNA $(0.0,0.2,0.4,0.6,0.8$, and $1.0)$, the relative viscosity of compound-DNA increases steadily, which proves that the compound binds to CT DNA

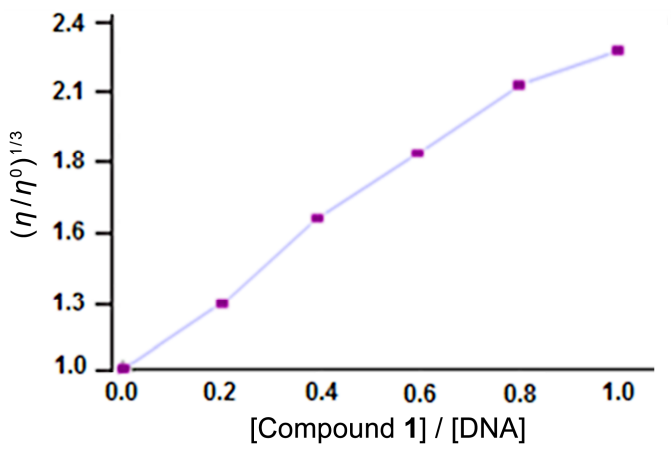

Figure 8. Change in viscosity of CT DNA with increasing concentration of compound1. Effect of increasing amount of compound 1 on the relative viscosities $\left(\eta / \eta_{0}\right)$ of CT-DNA at $25^{\circ} \mathrm{C}$ in Tris- $\mathrm{HCl}$ buffer at $\mathrm{pH}=7.2[\mathrm{CT}-\mathrm{DNA}]=[$ compound 1$]=0.1 \times$ $10^{-3} \mathrm{~mol} \mathrm{~L}^{-1}$ and the molar ratios of compound 1 / EB to DNA were $0.0,0.2,0.4,0.6,0.8$ and 1.0 . 


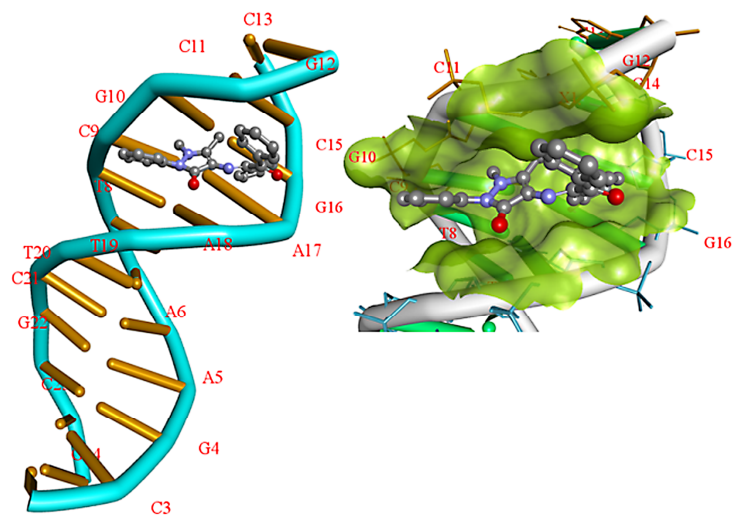

Figure 9. Docking representation of DNA with the compound 1 . The $\mathrm{N}-, \mathrm{C}-$, and $\mathrm{O}-$ termini of the compound 1 are shown as blue, grey, and red.

by intercalation. The increase in relative viscosity upon addition of compound 1 to CT DNA solution, causes the axial length of the DNA to increase, which corroborates the intercalating tendency of compound $\mathbf{1}$.

\section{MOLECULAR DOCKING STUDIES}

Computational studies through molecular docking are an attractive tool to probe the mechanistic details ${ }^{[33]}$ and mode of interaction between biopolymers and bioactive compounds. Docking studies were attempted to establish the type and the magnitude of interaction between the compound 1 and the CT DNA. In our experiments rigid molecular structure of DNA duplex with a sequence d(CGCGAAT TCGCG)2 dodecamer (PDBID : 1BNA) was taken, the finest fit orientation, and the lowest energy docked structure was analyzed. The study revealed that, initially compound 1 interacts with DNA via an electrostatic mode involving outside edge stacking interactions with the oxygen atom of the phosphate backbone of DNA. The docked structures shown in Figure 9 corroborate well with the experimental results and clearly indicate that the compound 1 fits snugly into the curved contour of the targeted DNA in the minor groove and is situated within a $\mathrm{G}-\mathrm{C}$ rich region, thus leading to Van der Waals interaction and hydrophobic contacts with the DNA functional groups that define the groove. ${ }^{[34]}$ In addition to this the phenyl ring of the compound $\mathbf{1}$ is arranged in an intercalative manner between the G10A and C11A of strand A of the DNA double helix. In this configuration, the N14 of the compound remains inclined towards the phosphodiester bond of DNA and hence the possibility of hydrogen bonding cannot be ruled out. The resulting relative binding energy of docked compound-DNA complex was found to be $226.52 \mathrm{~kJ} \mathrm{~mol}^{-1}$. High value of the binding energy indicates $\pi-\pi$ type of possible interaction between the phenyl ring of the compound $\mathbf{1}$ and the nucleotide base pairs of DNA in addition to the electrostatic and Vander Waals interaction. ${ }^{[35]}$ From the docking study, it can be concluded that binding studies of such type of molecules with DNA is credible and further work in this direction, is in progress.

\section{CONCLUSIONS}

In summary, a novel Combretastatin A4 analogue, compound 1, was synthesized under solvent free conditions using benzil and 4-aminoantipyrine. The compound 1 was spectroscopically examined and structurally characterized by single crystal $X$ ray diffraction study. The CT DNA binding propensity of the compound $\mathbf{1}$ was investigated by different biophysical methods of DNA binding (fluorescence, electronic absorption, ethidium bromide replacement, $C D$ spectroscopy, viscosity measurement and molecular docking studies). The DNA binding protocols undertaken in the present work were in agreement, with the primary intercalative mode of DNA binding for compound 1 . The significant DNA binding ability of compound 1 suggests, the possibility of DNA binding as the plausible mechanism of the Combretastatin anticancer activity. Furthermore, studies aimed at the targeted syntheses of electronically delocalized and sterically pre-organized Combretastatin analogues for exploration as DNA target agents and in the development of new cancer therapeutics is underway in our laboratory.

Acknowledgment. MAR thankfully acknowledges Dr. Atul Thawari IITB, Mumbai for CD Spectroscopy and Professor G.M Peerzada, Chairman Department of Chemistry University of Kashmir for kind support.

Supplementary Materials. CCDC-957471 contains crystallographic data for compound 1 . The data can be obtained free of charge via the Internet at http://www.ccdc.cam.ac.uk/ from the Cambridge Crystallographic Data Centre (CCDC), 12 Union Road, CambridgeCB21EZ, UK. email: deposit@ccdc.cam.ac.uk.

\section{REFERENCES}

[1] C. J. Li, B. M. Trost, Proc. Natl. Acad. Sci. U. S. A. 2008, 105, 13197.

[2] A. E. Latif, Phosphorus, Sulfur Silicon Relat. Elem. 2006, 181, 125.

[3] M. P. Pedro, A. M. Santos, J. N. Antunes, F. Eduarda, A. J. S. C. Vieira, Eur. J. Med. Chem. 2010, 45, 2258.

[4] R. M. Wadkins, J. L. Hyatt, X. Wei, J. Med. Chem 2005, 48, 2906.

[5] R. Nilson, M. Jain, M. Madhusudhan, N. Sheppard, N. G. Strittmatter, L. Kampf, C. Huang, J. A. Asplund, V. K. Mootha, Nat. Commun. 2014, 5, 3128.

[6] M. A. Rizvi, S. Guru, T. Naqvi, M.Kumar, N. Kumbhar, S. Akhoon, S. Banday, S. K. Singh, S. Bhushan, G. M. 
Peerzada, B. A. Shah, Bioorg. Med. Chem. Lett. 2014, 24, 3440.

[7] M. A. Rizvi, R. Maqsood, B. U. Khan, J. Chem. Educ. 2011, 88, 220.

[8] M. A. Rizvi, N. Teshima, S. R. Maqsood, S. A. Akhoon, G. M. Peerzada, Croat. Chem. Acta 2015, 88, 67.

[9] M. A. Rizvi, N. Teshima, G. M. Peerzada, Croat. Chem. Acta 2013, 86, 345.

[10] M. A. Rizvi, M. Zaki, M. Afzal, M. Mane, M. Kumar, B. A. Shah, S. Srivastav, S. Srikrishna, G. M. Peerzada, S. Tabassum, Eur. J. Med. Chem. 2015, 90, 876.

[11] Q. Guan, F. Yang, D. Guo, J. Xu, M. Jiang, C. Liu, K. Bao, Y. Wu, W. Zhang, Eur. J. Med. Chem. 2014, 87, 1.

[12] N. Boyle, M. Carr, L. M.Greene, O. Bergin, S. M. Nathwani, T. McCabe, D. G. Lloyd, D. M. Zisterer, M. J. Meegan, J. Med. Chem. 2010, 53, 8569.

[13] C. Rapp, P. Barbier, V. Bourgarel-Rey, C. Gregoire, R. Gilli, M. Carre, S. Combes, J. P. Finet, V. Peyrot, Biochemistry 2006, 45, 9210.

[14] R. Palchaudhuri, P. J. Hergenrother, Curr. Opin. Biotech. 2007, 18, 497.

[15] F. Arjmand, I. Yousuf, J. Organometal. Chem. 2013, 743, 55.

[16] N. Ljubijankić, A. Zahirović, E. Turkušić, E Kahrović, Croat. Chem. Acta 2013, 86, 215.

[17] I. Stolić, M. Avdičević, N. Bregović, I. Piantanida, L. Glavaš-Obrovac, Miroslav Bajić, Croat. Chem. Acta 2012, 85, 457.

[18] C. V. Kumar, E. H. Asuncion, J. Am. Chem. Soc. 1993, $115,8547$.

[19] I. T. Horváth, P. T. Anatas, Chem. Rev. 2007, 107, 2167.

[20] A. Santiago, Dalton Trans. 2013, 42, 8617.
[21] M. Nishio, Cryst. Eng. Comm. 2004, 6, 130.

[22] K. C. Skyrianou, E. K. Efthimiadou, V. Psycharis, A. Terzis, D. P. Kessissoglou, G. Psomas, J. Inorg. Biochem. 2009, 103, 1617.

[23] A. Wolfe, G. H. Shimer, T. Meehan, Biochemistry 1987, 26, 6392.

[24] H Lueng Chan, D. Lung Ma, M. Yang, C. Ming Che, J. Biol. Inorg. Chem. 2003, 8, 761.

[25] M. Howe-Grant, K. C. Wu, W. R. Bauer, S. J. Lippard, Biochemistry 1976, 15, 4339.

[26] S. Nafisi, A. A. Saboury, N. Keramat, J. F. Neault, H. A. Tajmir-Riahi, J. Mol. Struct. 2007, 827, 35.

[27] M. A. Husain, Z. Yaseen, S.U. Rehman, T. Sarwar, M. Tabish, FEBS J. 2013, 208, 6569.

[28] L. Messori, P. Orioli, C. Tempi, G. Marcon, Biochem. Biophys. Res. Commun. 2001, 281, 352.

[29] J. G. Collins, T. P. Shields, J. K. Barton, J. Am. Chem. Soc. 1994, 116, 9840.

[30] B. Selvakumar, V. Rajendiran, P. U. Maheswari, H. S. Evans, M. Palaniandavar, J. Inorg. Biochem. 2006, 100, 316.

[31] R. Marty, C. N. Nsoukpoe Kossi, D. Charbonneau, C. M. Weinert, L. Kreplak, H. A. T. Riahi, Nucleic Acids Res. 2009, 37, 849.

[32] L. Fin, P. Yang, J. Inorg. Biochem. 1997, 68, 79.

[33] M. Kumar, A. Kumar, M. Rizvi, M. Mane, K. Vanka, S. C. Taneja, B. A. Shah, Eur. J. Org. Chem. 2014, 1, 5247.

[34] R. Filosa, A. Peduto, S. D. Micco, P. de Caprariis, M. Festa, A. Petrella, G. Capranico, G. Bifulco, Bioorg. Med. Chem. 2009, 17, 13.

[35] Z. Yaseen, A. R. Banday, M. A.Hussain, M.Tabish, Kabir-ud-Din, Spectrochimica Acta, Part A: Mol. Biomol. Spec. 2014, 122, 553. 